\title{
ECONOMIC SECURITY ASSESSMENT SYSTEM OF ENTERPRISES IN EMERGENT SITUATIONS
}

\section{OLENA V. BAZHENOVA}

\section{Associate Professor}

Taras Shevchenko National University of Kyiv, Ukraine

bazhenova.olena25@gmail.com

\section{NATALIIA D. BELOUS}

Associate Professor

Academy of Labor, Social Relations and Tourism, Ukraine

ordnadi@ukr.net

\section{IHOR S.CHORNODID}

\section{Professor}

Academy of Labor, Social Relations and Tourism, Ukraine

chornodid@ukr.net

Abstract. The paper explores the economic security assessment system of enterprises in emergent states. The mechanism of economic security system evaluation that includes three stages (planning, implementation and results generating) has been proposed. At the stage of planning and preparation for the process of economic security system assessment the purpose and objectives of the evaluation system are formulated, the areas of assessment, methods and criteria of assessment are determined. The tasks of the assessment include the development of measures to respond to destabilizing phenomena and justify the possibilities of functioning in the new integrated environment. The next stage of evaluation that has been identified is an implementation of economic security assessment (evaluation of components and overall assessment of economic security system). In the paper, we have identified such components of enterprises' economic security as information, political, legal, resource, market, interface, innovative, environmental, social, etc. To evaluate the economic security' components we have proposed a score from 1 to 5 points, which characterizes the situation from poor (worst) to excellent (best). Finally, the last stage involves the evaluation and analysis of obtained results, protection of «weak» areas, working out of proposals for improving the efficiency of economic security system. Thus, economic security components of enterprises in emergent situations have been characterized. The proposed measures and proposals to eliminate the problematic aspects identified during the assessment will increase the level of economic security of the business as a whole and in emergencies in particular.

KEYWORDS: ECONOMIC POLICY, ECONOMIC SCIENCE, POLITICIZATION OF ECONOMICS, ECONOMIC REFORMS, HIGHPROFILE ECONOMISTS, INTERNATIONAL FINANCIAL INSTITUTIONS.

For citation: Bazhenova O.V., Belous N. D., Chornodid I. S. (2020). Economic Security Assessment System of Enterprises in Emergent Situations. Globalization and Business, №9, pp. 11-19. https://doi.org/10.35945/gb.2020.09.001

\section{INTRODUCTION}

Emergent situations both inside the country and in the world lead to the formation of destabilizing conditions for business entities functioning, which encourage the creation of platforms for rapid response to these factors based on effective management systems and economic security systems in particular. Emergencies, such as military actions and conflicts, pandemics affect almost all of the economic security components of country and business.
Well-timed effective assessment of the enterprises' economic security is formed to develop rapid response to destabilize economic phenomena, taking into account the factors influencing the negative trends, provide opportunities for a concise exit from crises, minimize the loss of economic benefits and create opportunities for further development in the new environment. The problem of implementation of modern and effective methods of assessment in Ukraine today takes special place among other urgent studies of economic science. Today, domestic enterprises dramatically 
require new assessment methods and capabilities that would meet current management and economic security needs, in particular, the realities of their operation and modern world trends.

The current necessity of Ukrainian enterprises to implement the economic security system in case of emergencies underscores the urgency of the problem. The rationale for the mechanism of rapid response to destabilizing economic phenomena and the development of practical measures for possibility of further functioning in new integrated environment determine the purpose of this study.

\section{ANALYSIS OF RECENT RESEARCH AND PUBLICATIONS}

The problem of effective methods of assessing the economic security in general and the economic security system of the enterprise, in particular, is not new and has been studied by many well-known practitioners and scientists.

In particular, Geets, Kizim, Chernyak and etc. (2006) note that in the system of national economic security a special place is occupied by the problem of economic security of enterprises, which has a dual nature. On the one hand, the operation of enterprises is carried out in a non-stationary external environment, and on the other hand, crisis trends at the micro level create the preconditions for negative trends in regional systems and reduce the level of national economic security.

Zabrodsky and Kapustin (1999) define economic security as «a quantitative and qualitative characteristic of the properties of the firm, reflecting the ability to selfsurvival and development in the face of external and internal threats». There is also an approach that emphasizes the main purpose of ensuring the enterprise's economic security is to achieve maximum stability regardless of objective and subjective threatening factors (Chumarin, 2003).

Varnaliy (2009) substantiates that the level of economic security of entrepreneurship is not a static indicator but includes three components such as the current level of economic independence of enterprises, the level of economic efficiency of enterprises, the ability to further development.

From the standpoint of external environment influence, the protection of enterprises from its negative impact and considers the content of the category of economic security of the enterprise by the authors (Cherep, Lubenets, 2010). Shlykov (1999) explains the economic security of the enterprise from the standpoint of minimizing losses and maintaining control over property.

Speaking about practical side of economic security of enterprise, to assess the economic security of the enterprise at the micro level, all indicators are divided into categories: financial indicators; production and sales; indicators of innovation activity; social indicators (Artemenko, Mishchuk, 2018).

However, despite significant existing research, a number of unresolved issues remain, including the formation of a coherent step-by-step mechanism for assessing economic security in emergent situations to implement a rapid response to destabilizing economic phenomena and develop practical measures for further development in an integrated environment.

\section{RESULTS}

Today, Ukraine along with countries all over the world is undergoing complex processes of adapting to emergent situations. The assessment of enterprises management system and its economic security system, in particular, aims to characterize the readiness of Ukraine and domestic businesses to respond to emergencies and opportunities to operate in the new integrated economic environment.

The process of assessing the economic security of enterprises is quite complex and paintaking, since it involves not only the formation of the characteristics of the economic activity of the subject, but also the degree of protection of these activities, etc. (Belous, 2016).

In general, we propose to implement the economic security system assessment mechanism in three stages: planning, implementation and results.

At the stage of planning and preparation for the process of evaluation of the economic security system, we propose to determine the purpose and objectives of the evaluation system, determine the scope, methods and criteria for evaluation (Table 1).

According to data in Table 1, the purpose of our assessment is to determine the state of the system of economic security of enterprises in the context of emergent situations in the country and all over the world. The tasks of the evaluation include the development of measures to respond to destabilize phenomena and justify the possibilities of functioning in the new integrated environment. In our opinion, an important task of assessing the economic security system is to identify the factors influencing the result.

With regard to the areas of assessment, we have selected an overall assessment of the economic security system based on separate assessment of its components, with the establishment of factors affecting the result. The evaluation of individual components in our opinion will allow us to identify the "weaknesses» and "strengths» of the whole system.

In order to carry out the evaluation of the enterprises economic security system, we have chosen quantitative methods in the form of point evaluation using graphical images for more visual representation and presentation of results.

The next stage of evaluation we have established is the stage of implementation-implementation of economic security assessment (evaluation of components and overall assessment of the economic security system). To assess the components of economic security, we propose a score of 1 to 5 points, which characterizes the situation from poor (worst) to excellent (best). It is also necessary to develop assessment criteria for each component and to characterize the scores.

In previous studies, we have summarized the following 
Table 1

Characteristics of the planning stage of the economic security assessment system

\begin{tabular}{|c|c|c|}
\hline Component & Meaning & Characteristics \\
\hline $\begin{array}{c}\text { Purpose } \\
\text { and } \\
\text { objectives }\end{array}$ & $\begin{array}{l}\text { Necessity of } \\
\text { providing an } \\
\text { assessment } \\
\text { of the system } \\
\text { during } \\
\text { emergencies } \\
\text { in order to } \\
\text { implement a } \\
\text { rapid } \\
\text { response to } \\
\text { destabilizing } \\
\text { phenomena }\end{array}$ & $\begin{array}{l}\checkmark \quad \text { To evaluate } \\
\text { the operation of the } \\
\text { economic security } \\
\text { system of business } \\
\text { and its individual } \\
\text { components; } \\
\checkmark \quad \text { To establish } \\
\text { factors of influence on } \\
\text { the received result; } \\
\checkmark \quad \text { To develop } \\
\text { measures to respond } \\
\text { to destabilizing } \\
\text { phenomena; } \\
\checkmark \quad \text { To } \\
\text { substantiate the } \\
\text { possibilities of } \\
\text { functioning in the } \\
\text { newly formed } \\
\text { integrated } \\
\text { environment as a } \\
\text { result of emergencies }\end{array}$ \\
\hline $\begin{array}{c}\text { Scope of } \\
\text { evaluation }\end{array}$ & $\begin{array}{l}\text { Evaluation of } \\
\text { all individual } \\
\text { components } \\
\text { and the } \\
\text { whole system }\end{array}$ & $\begin{array}{c}\checkmark \quad \text { To assess } \\
\text { individual } \\
\text { components of } \\
\text { economic security of } \\
\text { enterprises to identify } \\
\text { "weaknesses" and } \\
\text { "strengths" } \\
\checkmark \quad \text { To assess the } \\
\text { entire system of } \\
\text { economic security of } \\
\text { business in order to } \\
\text { develop a means of } \\
\text { responding to } \\
\text { destabilizing } \\
\text { phenomena }\end{array}$ \\
\hline $\begin{array}{l}\text { Definition } \\
\text { of } \\
\text { evaluation } \\
\text { methods } \\
\text { and criteria }\end{array}$ & $\begin{array}{c}\text { Quantitative } \\
\text { evaluation } \\
\text { methods }\end{array}$ & $\begin{array}{l}\checkmark \text { Development of } \\
\text { evaluation criteria } \\
\text { and characterization } \\
\text { of the score scale and } \\
\text { the system as a whole } \\
\text { for each component } \\
\text { of economic security; } \\
\checkmark \quad \text { Integration of the } \\
\text { results of the } \\
\text { assessment of the } \\
\text { components of } \\
\text { economic security } \\
\text { into a single indicator; } \\
\checkmark \quad \text { Implementation of } \\
\text { ranking and rating of } \\
\text { factors; establishment } \\
\text { of coefficients and } \\
\text { characteristics of the } \\
\text { scale for assessment } \\
\text { of factors. }\end{array}$ \\
\hline
\end{tabular}

economic security components of enterprises: information, political and legal, resource, market, interface, environmental, innovative and social components, etc.

Information security has come a long way from the use of naturally occurring information communications to the creation and development of global information and communication networks using space security. However, scientific and technological progress has led not only to the development and improvement of information support, but also to a number of problems related to its protection. Since 1973, communities have emerged as hackers, aiming at damaging the information security of individual users, organizations and entire countries. On the other hand, Google knows more about us than we know about ourselves: it creates an automatic profile with our master data; sends our coordinates and speed; saves our search history and more. It should be noted that, unlike the protection of state information, information protection of economic enterprises remains in the space of their personal problems. In addition, it should be stated that there is nothing "absolutely" confidential or protected and it can be considered to some extent impossible. Therefore, in our view, when evaluating an information component, it is necessary to focus not only on confidentiality, but also on the effectiveness of information, its validity and useful capabilities.

In the process of evaluating the information component of the business economic security system in emergent situations, we propose the following evaluation criteria: promptness and speed of receipt, reliability and verifiability, accessibility, integrity and authenticity, confidentiality and security, appeal and accountability. (Kharchenko, 2005) (Table 2).

Using the criteria for assessing the information component of economic security of enterprises, it can be stated that in most domestic enterprises the condition of the component corresponds to a high degree of protection and a score of 4 points. In recent years, the domestic information space has undergone a positive transformation, which provides business entities with the speed of obtaining, accessibility and authenticity, reliability and authenticity, etc. Some businesses have problems with accountability and appeal of the information space, which is explained by personal (private) factors, mainly the age barrier of staff and the logistics of resources. Also, it was noted that the confidentiality of information of business entities, its security is rather doubtful and a high degree of protection by this criterion is extremely rare.

If we study the aspect of implementation of information component in emergent situations, it is possible to confirm a sufficiently high degree of efficiency of its functioning. In emergencies, information systems and space are subject to the highest requirements, but it must be stated that the system is operating effectively. It should be noted that there are some failures in reporting systems, entities, banking systems, etc., but these failures are not systematic. Thus, a large number of company employees have switched to remote work, information flow for the needs of the company, its transfer, reporting and its mobility, the ability to 
Table 2.

Criteria for assessing enterprises information security

\begin{tabular}{|c|c|c|}
\hline Score & Characteristics \\
\hline 1 point & $\begin{array}{c}\text { The lowest degree of protection and efficiency of information use at the enterprise. The information is } \\
\text { not received in time, there are technical problems that do not allow using the Internet effectively, the } \\
\text { company uses unverified sources of information and its own information has a low degree of } \\
\text { protection. }\end{array}$ \\
\hline 2 points & $\begin{array}{c}\text { Low degree of protection and efficiency of information use at the enterprise. Information is not always } \\
\text { received on time, there are periodic technical problems that do not allow effective use of the Internet, } \\
\text { the company does not always use verified sources of information and its own information has a fairly } \\
\text { low degree of protection. }\end{array}$ \\
\hline 3 points & $\begin{array}{c}\text { The middle degree of protection and efficiency of information use in the enterprise. Information is } \\
\text { received on time, technical problems are almost absent, the Internet is used quite efficiently, the } \\
\text { company has access to verified sources of information, but its own information has a fairly low degree } \\
\text { of protection }\end{array}$ \\
\hline 5 points & $\begin{array}{c}\text { High degree of protection and efficiency of information use at the enterprise. Information is received in } \\
\text { a timely manner, the company uses professional maintenance services, modern and highly efficient } \\
\text { equipment, Internet space is used efficiently, the company has access to verified sources of } \\
\text { information, its own information has a high degree of protection }\end{array}$ \\
\hline $\begin{array}{c}\text { The highest degree of protection and efficiency of information use at the enterprise. The information is } \\
\text { received in a timely manner, promptly and is highly relevant, the company uses professional } \\
\text { maintenance services, modern and highly efficient equipment, the Internet is used efficiently, the } \\
\text { company has access to verified sources of information, its own information has the highest professional } \\
\text { level of protection }\end{array}$ \\
\hline
\end{tabular}

communicate and cooperate with contractors also provided information and Internet capabilities during emergencies quite successfully and at a high level.

The next component for the assessment of the economic security of enterprise we have substantiated the political and legal component, the assessment of which corresponds to the set mechanism in accordance with the stage of planning and preparation (definition of evaluation criteria, scoring, evaluation of these parameters). The study of this area allows us to conclude that the political and legal component, its state and characteristics in the domestic space is very unsatisfactory. Ukraine is currently in a state of constant change and reform, accompanied by changes in the legal field and a number of negative factors for the activities of economic entities. The constant change of regulatory and legal support entails not only additional costs for changes in software products, staff training, implementation, but also constant destabilization processes during business. Frequent changes of political and integration directions lead to crisis conditions and destabilization. For example, according to the Unified State Register of Legal Acts for 2019, more than 4,000 regulations were adopted in Ukraine. For comparison, the number of newly introduced legislation in the UK, Scotland, Wales and Northern Ireland, which is the leader in the adoption of acts among other European countries during this period, is about 200 .

The criteria for evaluating this component includes stability and consistency, focus on business support, transparency and clarity, legitimacy of government, and so on. By using the criteria for assessing the political and legal component of the system of economic security of business, we should state that in most domestic enterprises the stance of this component corresponds to a low level of protection and a score of 2 points. Despite the fact that business entities have learned to adapt to the constant destabilizing phenomena in the field of changing political directions and the legal framework, the number of enterprises that would withstand constant pressure from this component in the domestic space is constantly decreasing. The number of shadow businesses in Ukraine is not significantly decreasing, but on the contrary tends to increase. The vast majority of small businesses operating in the shadow explain the lack of registration not by refusing and unwillingness to pay taxes, but by fear of not understanding the legal framework, its imperfection, confusion, large number of reports, lack of tax holidays for seasonal business and high fines. If we study the aspect of the functioning of the political and legal component in emergencies, we can indicate a very low degree of protection and efficiency. The state hardly supports small and medium-sized businesses in emergencies, constantly lobbies for various types of assistance and benefits, etc.

The next component for the study of enterprises' economic security in emergencies is the interface one. The interface component is aimed at measures to protect relations with economic counterparties (suppliers, trade and sales intermediaries, investors, consumers, etc.) and to overcome the threats caused by possible unforeseen changes and circumstances (up to the termination of contractual relations). This component is in constant interaction with the political and legal component and to some extent is implemented 
depending on its condition. Examining the factors of interface component formation, we have found negative factors such as proximity to the government, constant lobbying of certain business interests by the government, low level of legitimacy of the government, significant problems with the judiciary that do not resolve disputes. It should be paid attention to the importance of interconnecting the interface component with another component of economic security of the business. In turn, opportunities for access to information databases of other contractors, verification of their reliability and business reputation are provided by the information component.

The evaluation criteria include duration of mutual settlements and their fluidity, reliability and integrity of mutual settlements, willingness and intention of counterparties to comply with contractual terms, protection from possible unforeseen changes from the point of view of the legal system, ability to respond to emergencies and more. The evaluation process according to the specified criteria is presented in table 3.

According to Table 3 in most domestic enterprises (except for retail sector), there is a focus on long-term settlements with counterparties due to greater opportunities and security from the emergence of unpredictable changes. The vast majority of domestic businesses focus on business reputation and value the data of trusted partners, working with them from year to year. We evaluated this criterion in «four» points.

Regarding the reliability and integrity of mutual settlements, we have given a score of "four» points, which is characterized by the verification of mutual settlements, the availability of information about the counterparty to a sufficient extent and the ability to establish intentions. Insecurity of Internet information, recommendations and reviews of other contractors, access to information databases in this case play a positive role and ensure the formation of this information.

Regarding the interface component, it is necessary to state the presence of desire to comply with the contractual terms. According to this criterion, it is possible to state the average level, which corresponds to the "three» points, as technical, resource, information and other business opportunities do not always allow to be a contractor.

Assessment of the criterion of protection against possible unforeseen changes from the point of view of the legal system leads to the conclusion that it is low. Research confirms the low level of protection against possible unpredictable changes and insufficient legal protection of domestic enterprises.

We have rated the ability of domestic enterprises to respond to emergencies to the highest score. Thus, it should be noted that during emergencies, mutual settlements of counterparties are positive. Because emergencies in the homeland occur quite often, the support of the state as usual is lacking, business entities have learned to adapt to them to be mobile, conscious and tolerant.

For this component of economic security of business, it can be calculated the average score for the assessment of the specified parameters. Thus, we can assess the interface component of economic security of business in "four» points, which is a positive value of the level and condition of this component in emergencies.

The next component for assessing the system of economic security of business, we have substantiated is the market one that reflects the degree of compliance of internal capabilities and potential of the enterprise to external needs and requirements in the market environment. The weakening of the market security of the enterprise is evidenced by such factors as reduction of market share owned by the enterprise; weakening of competitive positions and ability to counteract competitive pressure; reduction of adaptive capabilities of the enterprise to changes in the market, lag behind market requirements, etc. In Ukraine, there are some monopolists in the market of certain goods and services, which reduces opportunities for business development and competition. In addition, priority areas of economic activity are rarely supported by the state, which also reduces the adaptive capacity of enterprises. However, it is necessary to state the successful development of the Internet for the market of goods and services in recent years. Online sales of individual goods and services not only provide new opportunities and competitive advantages for business and the market, but also sometimes completely replace store sales, creating online markets and networks. The criteria for assessing the market component we have selected: market share of goods and services owned by an individual business entity; availability of potential and competitive advantages; adaptive capabilities of the enterprise (Table 4).

According to the data in Table 4, the degree of compliance of the internal capabilities of business entities with the external requirements and needs of the market at a fairly mediocre level generally corresponds to a score of "three» points. According to most criteria for assessing the level of the market component of economic security of business, domestic entities do not meet modern market requirements; have low adaptability, low competitive advantages, which in most cases is due to outdated material resources and overall market imperfections. Regarding the implementation of the market component of economic security of business during emergencies, it can be stated its low level and imperfection. Threats and destabilizing phenomena for the activities of enterprises caused by their inadequate internal capabilities with market needs are quite significant and probable.

Innovative component is one of the most important for ensuring a high level of economic security of the enterprise (Didenko, Motorna, 2018), (Dyachenko, Artemenko, 2014), (Kyrychenko, 2012), (Yankovets, Bondarenko, 2016). "Innovation is an activity that relates to the transformation of research and development, other scientific and technological achievements into a new or improved product introduced to the market, into a new or improved technological process used in practice, or a new approach to social services" (Dyachenko, Artemenko, 2014). The effectiveness of innovations directly depends on the assessment and examination of risks, as well as on methods of managing them.

The next stage of assessing the level of economic security we have substantiated is the "Stage of results 
Table 3.

The process of evaluating the interface component according to the specified parameters

\begin{tabular}{|c|c|c|}
\hline Criterion & \multicolumn{2}{|r|}{ Characteristics of points, determination of the corresponding point } \\
\hline \multirow{5}{*}{$\begin{array}{l}\text { Duration of mutual } \\
\text { settlements and their } \\
\text { fluidity }\end{array}$} & 1 & $<1$ year \\
\hline & 2 & $1-2$ years \\
\hline & 3 & $2-3$ years \\
\hline & 4 & Years \\
\hline & 5 & $>5$ years \\
\hline \multirow[t]{5}{*}{$\begin{array}{l}\text { Reliability and integrity } \\
\text { of mutual settlements }\end{array}$} & 1 & $\begin{array}{l}\text { Settlements are not checked, information on the counterparty is absent, reputation is not } \\
\text { known, intentions are not established }\end{array}$ \\
\hline & 2 & $\begin{array}{l}\text { Settlements are checked, information on the counterparty is not sufficient, information on } \\
\text { negative reputation is absent, intentions are not established }\end{array}$ \\
\hline & 3 & $\begin{array}{l}\text { Settlements are verified, information on the counterparty is present to some extent, } \\
\text { information on the reputation of the counterparty is positive, intentions are not } \\
\text { established }\end{array}$ \\
\hline & 4 & $\begin{array}{l}\text { Settlements are verified, information on the counterparty is present sufficiently, } \\
\text { information on the reputation of the counterparty is positive, intentions are established }\end{array}$ \\
\hline & 5 & $\begin{array}{l}\text { Mutual settlements are verified, information on the counterparty is sufficiently present, as } \\
\text { it is a well-known counterparty on the market, information on the reputation of the } \\
\text { counterparty is positive, intentions are established and directed and long-term calculations }\end{array}$ \\
\hline \multirow{5}{*}{$\begin{array}{l}\text { The desire and intention } \\
\text { of the contractors to } \\
\text { comply with the } \\
\text { contractual terms }\end{array}$} & 1 & $\begin{array}{l}\text { The counterparty does not intend to be the executor of contractual conditions and } \\
\text { realization of mutual settlements in the legal field }\end{array}$ \\
\hline & 2 & $\begin{array}{l}\text { The counterparty intends to be the executor of contractual conditions and realization of } \\
\text { mutual settlements in the legal field, however owing to the business opportunities hardly } \\
\text { fulfils these conditions }\end{array}$ \\
\hline & 3 & $\begin{array}{l}\text { The counterparty intends to be the executor of contractual conditions and realization of } \\
\text { mutual settlements in the legal field, however owing to the business opportunities will be } \\
\text { able to fulfil these conditions periodically not in full. }\end{array}$ \\
\hline & 4 & The counterparty intends and is almost always the executor of the contractual terms \\
\hline & 5 & $\begin{array}{c}\text { The contractor is a clear executor of contractual terms, intends to work in a well-founded } \\
\text { legal field }\end{array}$ \\
\hline \multirow{5}{*}{$\begin{array}{c}\text { Protection against } \\
\text { possible unforeseen } \\
\text { changes from the point } \\
\text { of view of the legal } \\
\text { system }\end{array}$} & 1 & There is no protection against possible unforeseen changes and legal protection \\
\hline & 2 & $\begin{array}{l}\text { Low level of protection against possible unforeseen changes and insufficient legal } \\
\text { protection }\end{array}$ \\
\hline & 3 & $\begin{array}{l}\text { Average degree of protection against possible unforeseen changes and average legal } \\
\text { protection }\end{array}$ \\
\hline & 4 & Sufficient protection against possible unforeseen changes and adequate legal protection \\
\hline & 5 & High degree of protection against possible unforeseen changes and high legal protection \\
\hline \multirow[t]{5}{*}{$\begin{array}{l}\text { Ability to respond to } \\
\text { emergencies }\end{array}$} & 1 & $\begin{array}{l}\text { Inability to respond to emergencies, lack of opportunities and desire to adapt to } \\
\text { emergencies, lack of mutual assistance and support }\end{array}$ \\
\hline & 2 & $\begin{array}{l}\text { Low level of response to emergencies, low capacity and willingness to adapt to } \\
\text { emergencies, lack of mutual assistance and support }\end{array}$ \\
\hline & 3 & $\begin{array}{l}\text { Average level of response to emergencies, average opportunities and desire to adapt to } \\
\text { emergencies, no mutual assistance and support }\end{array}$ \\
\hline & 4 & $\begin{array}{l}\text { Sufficient level of response to emergencies, sufficient opportunities and desire for } \\
\text { adaptation, mutual assistance in emergencies }\end{array}$ \\
\hline & 5 & $\begin{array}{l}\text { High speed of response to emergencies, high opportunities and desire to adapt, mutual } \\
\text { assistance in emergencies, understanding and support }\end{array}$ \\
\hline
\end{tabular}


and development of measures to improve efficiency and eliminate negative factors in the system of economic security of business.» This stage involves the assessment and analysis of the results, protection of «weak» areas, development of proposals to improve the efficiency of the economic security system.

According to the data, the lowest level of protection is observed in the political, innovative, legal and environmental components. Given the global trends in environmental protection, the focus of business on European markets and the requirements for environmental standards, the domestic business space is taking significant steps to minimize environmental pollution. This fact applies mainly to small businesses and is based solely on civic consciousness. Obsolescence of technical capabilities and resources, lack of effective legal framework, norms, environmental standards conditions, an important aspect is the development of effective measures to overcome crises and destabilization processes.

Generalized characteristics of the results of the assessment of the system of economic security of business in emergent situations are formed in Table. 5.

\section{CONCLUSIONS}

Thus, we have developed a set of proposals for measures to respond to problematic "weak» aspects identified because of assessing the components of the system of economic security of business in emergencies. We focus on the development of competitive advantages that will allow protecting business interests during emergencies. Constant renewal of funds and introduction of innovative technologies,

Table 4.

Estimation of a market component on the set parameters

\begin{tabular}{|c|c|c|c|c|}
\hline Score & $\begin{array}{c}\text { Market share of goods and } \\
\text { services of an individual business } \\
\text { entity }\end{array}$ & $\begin{array}{c}\text { The potential of the } \\
\text { enterprise }\end{array}$ & $\begin{array}{c}\text { Competitive advantages } \\
\text { of the enterprise }\end{array}$ & $\begin{array}{c}\text { Adaptive capabilities } \\
\text { of the enterprise }\end{array}$ \\
\hline 1 & - & - & - & - \\
\hline 2 & + & - & - & + \\
\hline 3 & - & - & - & - \\
\hline 4 & - & + & - & - \\
\hline 5 & - & - & - \\
\hline
\end{tabular}

create the possibility of environmental threats, their level is extremely high and protection from these threats is almost absent during emergencies.

The highest value in terms of the degree of protection for the components of economic security of business is obtained for the information and interface component.

Social, resource and market components of the economic security of enterprise received the average value, which corresponds to the score "three». In Ukraine, in recent years, penalties for violations of labor legislation have significantly increased, which has undergone a large number of changes, which should encourage to increase the level of this component. However, currently there is a lack of support from the state, preferential conditions for social entrepreneurship, especially during emergencies. Contradictions regarding the main goal in social entrepreneurship, the availability of profit and state preferences significantly complicate their successful implementation in the system of economic security.

Transformation of any social, economic and political system mostly takes place in emergencies, such as epidemics and pandemics, military events, occupation, temporary resettlement, etc. These transformations under the influence of various factors can become a direct threat to the existence of components of economic security of business. Under these creation of reserve funds and anti-crisis management system, development of corporate eco-culture, introduction of own social standards - in our opinion will ensure the development of competitiveness of domestic businesses, and on this basis increase their economic security.

Studies of the system of assessing the economic security of business in emergencies allow drawing the following conclusions. We have proposed a step-by-step evaluation mechanism based on the evaluation of the components of the economic security system. This requires applying quantitative methods based on a score scale for given parameters. The average value of the evaluation of all components is "three» points, which means the average degree of protection and efficiency of the economic security of business in emergencies. Thus, the response to processes and phenomena that occur in the country or all over the world during emergencies under the influence of internal and external factors is quite weak, quite destabilizing the activities of economic entities. The proposed measures and proposals to address the problematic aspects identified during the assessment, in our opinion, will increase the level of economic security of business in general and during emergencies in particular. 
Table 5.

Stage of results and development of measures to improve efficiency and eliminate negative factors in the system of economic security of business

\begin{tabular}{|c|c|c|c|c|}
\hline $\begin{array}{l}\text { Economic security } \\
\text { components }\end{array}$ & $\begin{array}{l}\text { Avera-ge } \\
\text { value }\end{array}$ & $\begin{array}{l}\text { Result of } \\
\text { assess-ment, } \\
\text { score }\end{array}$ & $\begin{array}{l}\text { "Weak" areas, negative } \\
\text { values by criteria }\end{array}$ & Threat prevention measures \\
\hline Information & \multirow{7}{*}{3} & 4 & $\begin{array}{l}\text { Accountability and appeal; } \\
\text { Security }\end{array}$ & $\begin{array}{c}\text { Staff training, introduction of innovative } \\
\text { technologies, introduction of anti-virus and anti- } \\
\text { hacker products }\end{array}$ \\
\hline Political and legal & & 2 & $\begin{array}{l}\text { Losses under contracts } \\
\text { from changes in } \\
\text { legislation, } \\
\text { and fines for violating it }\end{array}$ & $\begin{array}{l}\text { Creation of reserve funds to cover losses and } \\
\text { losses from changes in legislation. Use of certified } \\
\text { products for changes and innovations in the } \\
\text { regulatory system. Qualified legal protection }\end{array}$ \\
\hline Interface & & 4 & $\begin{array}{l}\text { Losses from non-fulfilment } \\
\text { of contractual conditions, } \\
\text { dishonesty of contractors }\end{array}$ & $\begin{array}{l}\text { Creation of reserve funds for overcoming crisis } \\
\text { situations, cooperation with proven contractors } \\
\text { with a positive professional reputation }\end{array}$ \\
\hline Market & & 3 & $\begin{array}{l}\text { Decreased market share, } \\
\text { loss of competitive } \\
\text { advantage }\end{array}$ & $\begin{array}{l}\text { Anticipation of market fluctuations and increase of } \\
\text { competitive advantages, development of Internet } \\
\text { business environments, use of innovative } \\
\text { marketing technologies }\end{array}$ \\
\hline Resource & & 3 & $\begin{array}{l}\text { Obsolescence of material } \\
\text { and technical resources } \\
\text { and their low adaptive } \\
\text { capacity, lack of } \\
\text { competitive resource } \\
\text { advantages }\end{array}$ & $\begin{array}{l}\text { Improving the level of competence and } \\
\text { professionalism of staff, their competitive } \\
\text { advantages. Introduction of crisis management } \\
\text { system. Constant updating of production and } \\
\text { technical resources and introduction of innovative } \\
\text { technologies, expansion of the range of } \\
\text { investment resources and projects, etc. }\end{array}$ \\
\hline Ecology & & 2 & $\begin{array}{l}\text { Environmental pollution, } \\
\text { harmful working } \\
\text { conditions for staff }\end{array}$ & $\begin{array}{l}\text { Introduction of innovative technologies focused on } \\
\text { ecological business projects, development of own } \\
\text { eco-standards, development of corporate eco- } \\
\text { culture. Improving working conditions and } \\
\text { developing standards for personnel protection }\end{array}$ \\
\hline Social & & 3 & $\begin{array}{l}\text { Low level of social } \\
\text { protection }\end{array}$ & $\begin{array}{l}\text { Development of own social programs and projects } \\
\text { for staff, creation of inclusive jobs, improvement } \\
\text { of working conditions }\end{array}$ \\
\hline Innovative & & 2 & $\begin{array}{l}\text { Low level of innovations } \\
\text { production }\end{array}$ & $\begin{array}{c}\text { Development and effective using of innovation } \\
\text { products }\end{array}$ \\
\hline
\end{tabular}

\section{REFERENCES}

Artemenko, L. P., Mishchuk, Y.S. (2018). Management of the enterprise economic security in the conditions of European integration. https://www.google.com/search?rlz=1C1AOHY_ruUA900\&q=economic+security+of+the+company\&sa=X\& ved=2ahUKEwiNn-qx3aPpAhVHEncKHc-cAdAQ1QIoBXoECAsQBg\&biw=1040\&bih=668. (In Ukrainian)

Belous, N. (2016). Stage of planning in the system of economic security assessment of enterprises. Bulletin of Khmelnytsky National University. № 2, pp. 12-17. (In Ukrainian)

Cherep, A., Lubenets, I. (2010). Conceptual principles of economic security of enterprises: Bulletin of Zaporizhia National University. №1 (5). pp. 63-66. http://web.znu.edu.ua/herald/issues/2010/Vest_Ek5-1-2010-PDF/062-66.pdf (In Ukrainian)

Chumarin, I. (2003). Personnel safety. Personnel of the enterprise. №3. (In Ukrainian)

Didenko, E., Motorna, Yu. (2018) Peculiarities of forming the innovation security of enterprise. Efektyvna Ekonomika. No.1. Accessed 31.03.2020 http://www.economy.nayka.com.ua/pdf/1_2018/46.pdf

Dyachenko, O, Artemenko, L. (2014) The Innovative Component of Economic Security of Enterprise. https://ela.kpi.ua/bitstr eam/123456789/13903/1/2014_4_Dyachenko.pdf (In Ukrainian)

Geets, V., Kizim, M. Chernyak, O. etc., (2006). Modeling of economic security: state, region, enterprise. Monograph. 240p. (In Ukrainian) 
Kharchenko, B. C. (2005). Information security. Glossary. K. KHT. (In Ukrainian)

Kyrychenko, O. (2012). Innovation security as an integral component of economic security and efficient project-focused developemnt of modern enterprises. http://fkd.org.ua/article/viewFile/28783/25811 (In Ukrainian)

Shlykov, V. (1999). Integrated Maintenance of the Economic Security of an Enterprise. St. Petersburg. (In Russian)

The UK legislation. Accessed 31.01.2020 http://www.legislation.gov.uk/new/uk/2019-01-31.

Unified State Register of Legal Acts. Accessed 31.01.2020 https://www.reestrnpa.gov.ua/REESTR

Varnaliy, Z. etc. (2009). Economic security: a textbook. Kyiv (In Ukrainian)

Yankovets, T., Bondarenko, A. (2016). The role of innovations in ensuring the economic security of enterprise. Accessed 31.03.2020. https://er.knutd.edu.ua/bitstream/123456789/4854/1/20160527IAZ_P201-203.pdf

Zabrodsky, V., Kapustin N. (1999). Theoretical foundations for assessing the economic security of the industry and the company. Business Inform. No. 15-16, pp. 35-37. (In Ukrainian) 